\title{
The Effect of Picture Story Books on Students' Reading Comprehension
}

\author{
Roslina \\ English Departement, FKIP, Universitas Sembilanbelas November Kolaka, Jl. Pemuda No. 339 Kolaka Southeast Sulawesi, Indonesia \\ E-mail: roslina@usn.ac.id
}

Doi:10.7575/aiac.alls.v.8n.2p.213

URL: http://dx.doi.org/10.7575/aiac.alls.v.8n.2p.213
Received: 11/03/2017

Accepted: 23/04/2017

\begin{abstract}
As a non formal education students, PKBM (a Non-Formal Community Learning Center) Medaso Kolaka students tend to encounter some difficulties in reading such as low motivation, infrequent tutors (non-formal education teachers) coming, inappropriate teaching materials, etc. This research aimed to investigate the effects of picture story books on the students' reading comprehension and to clarify students' perception on the utilization of picture story books in teaching reading. The research was conducted at the PKBM Medaso Kolaka by applying the experimental design. There were 15 students randomly took as the sample and they were taking a Paket B. The sample was divided into two groups, namely experimental group and control groups. The data were collected by administering a test, namely pre-test that aimed to determine the prior students' knowledge, and the post-test that was conducted in the end of the experiment. Questionnaires and interviews were also used to collect data of the students' perception. Then, the data were analyzed by using Pearson Product Moment assisted by SPSS 14.0. The results revealed that picture story books were able to improve students' reading as well as the students' interest in reading. The result showed that the utilization of picture story books had effect on the students' reading comprehension that revealed the value of 0.025 with higher scores found in the post-test.
\end{abstract}

Keywords: picture story books, teaching reading, reading comprehension, PKBM Medaso Kolaka

\section{Introduction}

Language is an important part of human for communication. By a language, people are able to convey ideas, mind, opinion and feeling. Furthermore, since every country has its own language, people need an international language to match people global need. For that reason, there are a lot of people was mastering English as their foreign language.

Later on, as reading a lot can enrich students vocabulary mastery, so the researcher thinks that to improve the lower English proficiency students, reading activity is one alternative solution. In addition, the researcher has done a preliminary research on August, 25th of 2009 at PKBM Medaso Kolaka and she found that the students of PKBM Medaso Kolaka tend to encounter some difficulties in reading such as low motivation, infrequent tutors' (non-formal education teacher) coming, inappropriate teaching materials, etc. So, the researcher was thought to treat the PKBM Medaso student with reading activities.

In other hand, PKBM Medoso students hold that learning English is a difficult task and they also think that reading is a stressing activity. So in the reading class performance, it is found that the students didn't read the text; they chat each other with different topic discussion; and join the class as formalization only. It is not only because of the hot atmosphere of the classroom, or the unkind tutors who almost leave their class, but also the inappropriate teaching method and materials used.

Based on the reality above, the English tutor at PKBM Medaso Kolaka need to improve their performance as well as to improve the students' reading comprehension. The tutor should create an interactive reading activities as well as guiding the students to enjoy the reading activity.

The researcher supposes that the use of pictures as a visual media in the teaching learning process is intended to make the teaching learning more effective and efficient. When the teaching learning effective and efficient means the quality of learning outcomes can be improved. This idea is in line with Pan et. All (2009) who investigated the extension of pictures preference in text towards the low-proficiency Taiwanese English foreign language (EFL) college students. They found that the low-proficiency participants had significantly higher scores on their translation task when the text was presented together with the pictures.

Other research also did by Riyadi (2010) which investigated the elementary students' performance during the utilization of story books in the reading class. The goal of his research was to describe the teaching of the English used story book for elementary school. At last, he concluded that story book could stimulate and motivate students' interest and was not boring for the children. 
Unlike Pan and Pan (2009) and Riyadi (2010), Jalilehvand (2012) also conducted a research which tried to find out the effectiveness of text length and pictures in the reading performance of Iranian EFL students. And she started to combine text and picture. She introduced dual coding theory as her fundamental theory.

As well as the dual coding theory is one theory which elaborates the effect of imagery in a picture with someone reading performance. Pivot cited from Pan et. All (2009:2) showed that when someone receive a single verbal information, then it will run in the verbal system. As like as, when someone receives a visual information, it will run into the imaging system.

Paivo's statement linear with Sadoski, et all (2000:1) who stated that "A basic assumption of dual coding theory is that the effects of the two codes are additive, so that memory is increased when both verbal and nonverbal codes are activated, other things being equal". So, researcher holds that when a reading text present with pictures means that the students reading comprehension will be facilitated.

Regarding to the PKBM Medoso student's condition; and also based on those three results of the previous studies above, the researcher decides to use picture story books to improve the students' reading comprehension at PKBM Medaso Kolaka. The researcher draws two research objective, namely the effects of picture story books on students' reading performance and students' perception towards the utilization of picture story books in reading class.

\section{Research Methodology}

\subsection{Design of the Research}

To answer the research question as well as "to what extend does the use of picture story books in teaching English reading improve the reading performance for the first year of Paket B PKBM Medaso Kolaka? And what are the students' perceptions towards the utilization of picture story books in reading class?", the researcher applied an experimental research which intake two groups namely experimental group and control group. Both of them were following a pre test and post test. In addition, the design followed the design research which adapted from Gay, et all (2006) as follows:

\begin{tabular}{cccc} 
EG & O1 & X1 & O2 \\
\hline CG & O1 & X2 & O2
\end{tabular}

Where:

$\begin{array}{ll}\text { EG } & \text { : Experimental Group } \\ \text { CG } & \text { : Control Group } \\ \text { O1 } & \text { : Pretest } \\ \text { O2 } & \text { : Posttest } \\ \mathrm{X} 1 & \text { : Treatment with picture story books } \\ \mathrm{X} 2 & \text { : treatment without picture story books (conventional teaching) }\end{array}$

\subsection{Location of the Research}

This research had been conducted at the first year of Paket B PKBM Medaso Kolaka which is located in Kolaka city, Southeast Sulawesi. The researcher chosen this institution as the location of the research based on some reasons. The researcher had been taught for five years in this PKBM and the researcher found that the PKMB's policy does not match with the students' need perfectly.

\subsection{Population and Sample}

From preliminary research it was found that the students PKBM Medaso Kolaka had different performance in reading. So based on Teddlie (2007:77-78), the researcher applied purposive sampling technique to determine that the 30 students who were coming from the year 2011/2012. Then, the researcher divided that students into two different groups. 15 students were in the experimental group while the remaining were in the control group.

\subsection{Procedure of Collecting Data}

The researcher was gathering the data through questionnaire, reading test, observation sheet, and interview.

\subsection{Techniques of Data Analysis}

The students' reading comprehension had been measured by using SPSS program. The result has been compared to see whether there is improvement from pretest and post test. The students score was formulated by using Depdiknas (2006) as:

$$
\text { A Student score }=\frac{\text { the gain score }}{\text { the maximum score }} \times 100
$$

The classification of the student's score as follows:

95 to $100 \quad$ : is classified as Excellent

85 to $94 \quad$ : is classified as very good 


$\begin{array}{ll}75 \text { to } 84 & \text { : is classified as good } \\ 65 \text { to } 74 & \text { : is classified as fairly good } \\ 55 \text { to } 64 & \text { : is classified as fair } \\ 35 \text { to } 54 & : \text { is classified as poor } \\ 00 \text { to } 34 & : \text { is classified as very poor }\end{array}$

\section{Findings}

\subsection{Students' Pre-Test Result}

The first hypothesis (H1) of this research was answered in table 1.

Table 1. The Pre-Test Score of Students' Reading Performance

\begin{tabular}{lllllll}
\hline No & Name & \multicolumn{2}{c}{ Control Pre-test } & Name & \multicolumn{2}{l}{ Experimental Pre-test } \\
& & Score & Classification & & Score & Classification \\
\hline 1. & EM & 68 & Fairly Good & RJ & 84 & Very Good \\
2. & HH & 44 & Poor & WB & 76 & Good \\
3. & JQ & 32 & Very Poor & ARA & 68 & Fairly good \\
4. & SB & 36 & Poor & SN & 68 & Fairly good \\
5. & AF & 40 & Poor & RF & 36 & Poor \\
6. & AR & 44 & Poor & ARS & 40 & Poor \\
7. & AR & 40 & Poor & GG & 80 & Good \\
8. & SE & 52 & Poor & AR & 64 & Fair \\
9. & EA & 48 & Poor & IF & 76 & Good \\
10. & AR & 60 & Fair & NS & 88 & Very good \\
11 & AG & 60 & Fair & AI & 36 & Poor \\
12 & MA & 32 & Very poor & SN & 52 & Poor \\
13 & SD & 60 & Fair & FD & 68 & Fairly Good \\
14 & MC & 36 & Poor & NM & 56 & Fair \\
15 & AJ & 44 & Poor & AA & 36 & Poor \\
& Mean & 46,4 & Poor & Mean & 61,8 & Fair \\
\hline
\end{tabular}

The table showed that the reading performance of students in the control group is still below the standard. None of the students scored good, very good, and excellent. Compared to the experimental group, the students' reading performances are fair. It means that although none of the students scored excellent, there were students who scored very good, good, and fairly good.

In control class, only 1or $7 \%$ student got fairly good, 2 or $13 \%$ students got fair, 10 or $67 \%$ students got poor, and 2 or $13 \%$ students got very poor. In experimental class, there were 2 or $13 \%$ students got very good, 3 or $20 \%$ students got good, 3 or $20 \%$ students got fairly well, 2 or $13 \%$ students got fair, 4 or $27 \%$ students got poor, and only 1 or $7 \%$ got very poor. From the calculation of the mean score, the experimental mean score is 61.8 and it is categorized into fair while the control group is 46.4 which is categorized into poor.

\subsection{Students' Post-Test Result}

Table 2 shows that none of the students in control group positioned on the lowest and highest score. It means that nobody gets very poor and excellent. Comparing to the experimental group, there is a student who gets score excellent which is the highest score and none of the students gets the lowest score.

Table 2. The Rate Percentage of Post-Test Score of the Control Group (C) and Experimental Group (E)

\begin{tabular}{llllll}
\hline Classification & Score & Post-Test C & \multicolumn{2}{l}{ Post-Test E } \\
& & F & $\%$ & F & $\%$ \\
\hline Excellent & 95 to 100 & - & - & 1 & 7 \\
Very Good & 85 to 94 & - & - & 4 & 27 \\
Good & 75 to 84 & 1 & 7 & 3 & 20 \\
Fairly Good & 65 to 74 & 5 & 33 & 3 & 20 \\
Fair & 55 to 64 & 4 & 27 & 4 & 27 \\
Poor & 35 to 54 & 5 & 33 & - & - \\
Very Poor & 00 to 34 & - & - & - & - \\
Total & & 15 & 100 & 15 & 100 \\
\hline
\end{tabular}


In the control group, there are 1 or $7 \%$ student got well, and followed by 5 or $33 \%$ students got fairly good and 4 or $27 \%$ students got fair. Despite the fact that none of the students got very poor, there is still a disappointing fact that there are 5 or $33 \%$ students got poor score. In the experimental group, it can be seen that there is 1 or $7 \%$ student get excellent, 4 or $27 \%$ students got very good, 3 or $20 \%$ students got good, 3 or $20 \%$ students got fairly good and 4 or $27 \%$ students got fair. None of the students in this group gets poor and very poor. It can be concluded the experimental class and the control class showed significant improvement of their own pre-test to post-test.

\subsection{The Improvement of the Experimental Class}

Table 3 verifies that the pre-test and post-test score of the experimental group was showing different.

Table 3. The Classification and percentage of Experimental Group

\begin{tabular}{llllll}
\hline Classification & Score & Pre-Test & & Post-Test & \\
& & F & $\%$ & F & \% \\
\hline Excellent & 95 to 100 & - & - & 1 & 7 \\
Very Good & 85 to 94 & 2 & 13 & 4 & 20 \\
Good & 75 to 85 & 3 & 20 & 3 & 20 \\
Fairly Good & 65 to 74 & 3 & 20 & 3 & 27 \\
Fair & 55 to 64 & 2 & 13 & 4 & - \\
Poor & 34 to 54 & 4 & 27 & - & - \\
Very Poor & 00 to 34 & 1 & 7 & 100 \\
Total & & 15 & 100 & 15 & 100 \\
\hline
\end{tabular}

In the pre-test, there are 2 or $13 \%$ students who got very good, 3 or $20 \%$ students got good, 3 or $20 \%$ students got fairly good, 2 or $13 \%$ students got fair, 4 or $27 \%$ students got poor, and 1 or $7 \%$ student got very poor. While, the students' scores on post-test were increased. It can be seen that there is 1 or $7 \%$ student got excellent, 4 or $27 \%$ students got very good, 3 or $20 \%$ students got better, 3 or $20 \%$ students got fairly good, and 4 or $27 \%$ students got fair. None of the students in this group gets poor and very poor. It can be concluded that experimental class showed a significant improvement from their pre-test to post-test.

\subsection{The Improvement of Control Class}

Table 4 illustrated that in the students' post-test of control group, there were 1or 7\% student got good, and followed by 5 or $3 \%$ students got fairly good and 4 or $27 \%$ students got fair. Despite the fact that none of the students got very poor, there is still a disappointing fact that there are 5 or $33 \%$ students got poor score.

Table 4. The classification and Percentage of Control Group' Score

\begin{tabular}{llllll}
\hline Classification & Score & Pre-Test & \multicolumn{2}{l}{ Post-Test } \\
& & F & $\%$ & F & $\%$ \\
\hline Excellent & 95 to 100 & & & - & - \\
Very Good & 85 to 94 & - & - & - & - \\
Good & 75 to 84 & - & - & 1 & 7 \\
Fairly Good & 65 to 74 & 1 & 7 & 5 & 33 \\
Fair & 55 to 64 & 2 & 13 & 4 & 27 \\
Poor & 35 to 54 & 10 & 67 & 5 & 33 \\
Very Poor & 00 to 34 & 2 & 13 & - & - \\
Total & & 15 & 100 & 15 & 100 \\
\hline
\end{tabular}

\subsection{Students' Perceptions Towards the Utilization of Picture Story Books in Reading Classroom Data From Questionnaire and Interview}

The students' perception analysis towards the utilization of picture story books in the reading classroom describes into data from questionnaires and data from the interview. The percentage of students' response towards the utilization of picture story books could show in figure 1 . Figure 1 shows that $70,5 \%$ students were strongly agreed. Then, $28,2 \%$ students were agreeing. While the remaining or 0.65 students were not answering. 


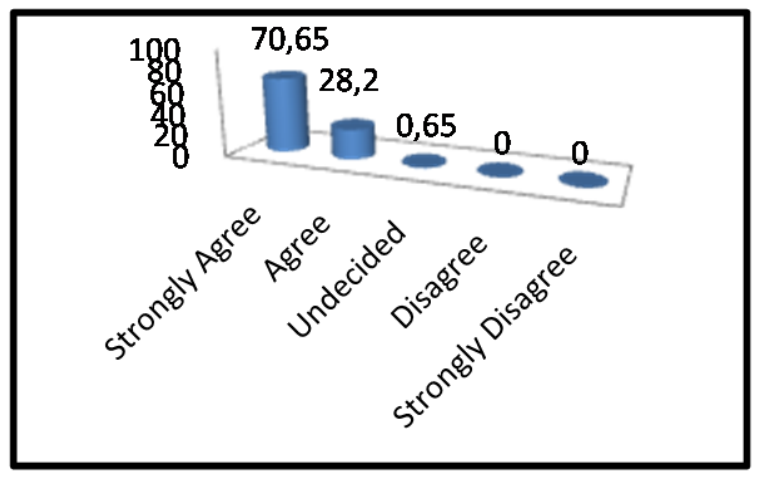

Figure 1. The diagram of students' responses mean score percentage

\section{Discussion}

The finding of this research described from the gathered data which taken from pre-test and post-test. As mentioned in the previous section that the two students' group reading performance been improved significantly. At pre-test, the experimental group mean score is 61.8 while the control group mean score is 46.4. It means that the control group and the experimental group showed a significant difference in their previous performance.

The researcher also found that the t-observed is 2.653 and the t-table is 2,048 at 0.05 levels, where T-observed > Ttable, $\alpha=0.05$. In addition, the Sig. (2-tailed) is 0,009 and it is higher than 0.05 . It can be concluded that both of the experimental group and control group show different performance.

From Butcher et all. (2000) found that benefits in the temporal association of visual and verbal information, where it is presenting visual and verbal sources at the same time leads to better learning than presenting them at different times. In line with Ryu (2000) who said that dual coding theory presented an issued than when we have more than one information process system, which implies that it would be better if we use two sources information in learning activities. This statement approved in by the expriment group comprehension improvement. In pre test, this group means score is 61.8 then it is being improved to be 75.3 in post-test. The mean difference is calculating as well as $75.33333-61.8666=13.46673$ while it standard deviation is 7.30753. Then, the researcher calculate and t-table is Tobserved (7.632) $>$ T- table (2,145), $\alpha=0.05$ ). at 0.05 levels of significant at 14 degrees of freedom. So, Sig. (2-tailed) is 0.00 which is lower than 0.05 .

The control group also show an improvement but not as good as the experimental group. In the pre test, this grout got mean score 46.4 and in the post test they got mean score 55.7. The standard deviation is 6.71672 while the mean difference in pairs sample test is 9.33333 which is came from the calcultation of $55.73333-46.4000$. In addition, the researcher found that T-observed (4.382) > T-table (2.145), $\alpha=0,05)$ Sig. (2-tailed) is 0,001 which is lower than 0.05 . It means that the data from pre-test and post-test of control group also show an improvement. This was supported Pan and Pan (2009), Riyadi (2010), and Jalilehvand (2012) who also found a greater signifacant improvement after the treatment of pictures.

Data from questionnaires and interviews in line with Paivo (2006) who mention that in the dual coding theory words and images have different cognitive representations, they are the verbal system and the imagery system when those two systems work together the comprehension performed well. The improvement of students' performance in reading has an independence correlation with the questionnaires. The finding verifies that the highest rank of the mean score is 70 , $65 \%$ of strongly agree students. The second is 28 or $2 \%$ of agree students. There is $0.65 \%$ of neutral answer (undecided), and) $0 \%$ of disagree and strongly disagree statement. The individual interview on the participant's response towards the use of picture story books in the experimental group revealed that all of the students highly valued the importance of picture story books in the reading class on answering the first question.

If you ask about 'is picture effect students' English performance?' so you address your question to Pan and Pan (2009), Riyadi (2010), and Jalilehvand (2012) directly; the general consensus is that visuals with text have positive effects on reading comprehension. Within the context of those researches, "visuals" refer to any graphic displays (either in dynamic or static form) that depict all or some of the accompanying text's content.

The results of those three researches indicate that when pictures were presented with the body of the reading text, the performance of the students would be increasing. In kind of these accompanying pictures simplified students performance not only in the simple but also the more difficult reading text.

In this research, the pictures could not be stored in the verbal system because they are not verbal; they could, however, be stored in the imagery system and associations could be drawn with their respective text descriptions from the verbal system. Dual coding is answering of why pictures facilitate students reading comprehension. The students who treated with pictures are more active because the presenting of pictures encourages students to know the meaning of the text.

In reading activity, students' brain is active to analyze and to compare the visualization of the pictures and the text. If they are error on the text's linguistic input as well as their poor vocabulary and structure pattern which may lead them in 
difficulty reading time. Here, the students' difficulties of language input will be facilitated by presenting pictures. In this research, the researcher find that lower level students are being encouraged their motivation.

In detail, there are also significant reasons of the students' improvement in reading skill through picture story books. At first, the tutor posted a big picture on the blackboard, the crowded class began to focused on the picture, such of them asked "what picture is it?", and "what for its it?". Then, the tutor wrote a capital letter above it. Then the students gave such comment of the picture likely, "oh, I know, it is a big fish", others said "yeah, underwater environment", etc. It can be said the picture is stimulating students' imagination.

Second, the tutor told them that the picture has a complete story. So, the students asked the tutor the tutor to share the picture story book. It means that picture story books can stimulate students to put more effort to read since their reading accompanied with pictures. It encourages them to read more and learn to improve their stories and picture story books can stimulate students' motivation to learn English reading.

At the third, the tutor grouped the students into 4 groups. Then, tutor share the whole pictures without text and the text separated for each group. The tutor asked the students to match the picture and the text. Each group decided the task for each member, there is one who found the meaning of the word in the dictionary, there is other write the meaning, there is also translated the text, and the other tried to match the picture with the text after reading the translation of the text. By those conditions, picture story books give students an opportunity to learn together. Or in other words, picture story books can create a learning community in the classroom.

After all the pictures and the text matched, the tutor asked the students to arrange the pictured into a good organization. At that time, each group had a different way to settle that problem. There is one group started by retranslating the text, there is also started by arranged the picture without looking the text. It showed that Pictures can stimulate students' creativity, develop students' capacity for self-assessment and critical thinking skills.

When the whole pictures organized into a correct arrangement, the tutor asked the students retold the story in front of the class, individually. In the fist and second meeting, there was none of the students come. But in the third meeting, there were such enthusiast and be confidence to come in front of the class. In other word, picture story books growth confidence and develop students' autonomy to learn.

Those all condition above showed that by picture story books students can gain more knowledge to improve their own reading.

In another case, the students' enthusiast began to decrease in the fifth meeting. Settling into this problem, the researcher asked the students' reasons. One of the students said that "I like picture story books, but if it comes every time, fell boring for me, I need something more". The other also said that "we have learned picture story book too much, give us another material". This situation came, as the effect of the frequently same types materials came in a short time duration. So, the researcher suggested the next researcher to implement their treatment by aware their respondents' time.

Connecting the situation above and the grand theory of dual coding, the researcher concluded that the picture story books worked well as one type of media which helpful in reading. In other words, the text of the story present as the verbal information and the pictures as the visual image. Then, when it presented to the students' as teaching material,

The students' response towards the utilization picture story books could find as figure 2.

Procedure of teaching:

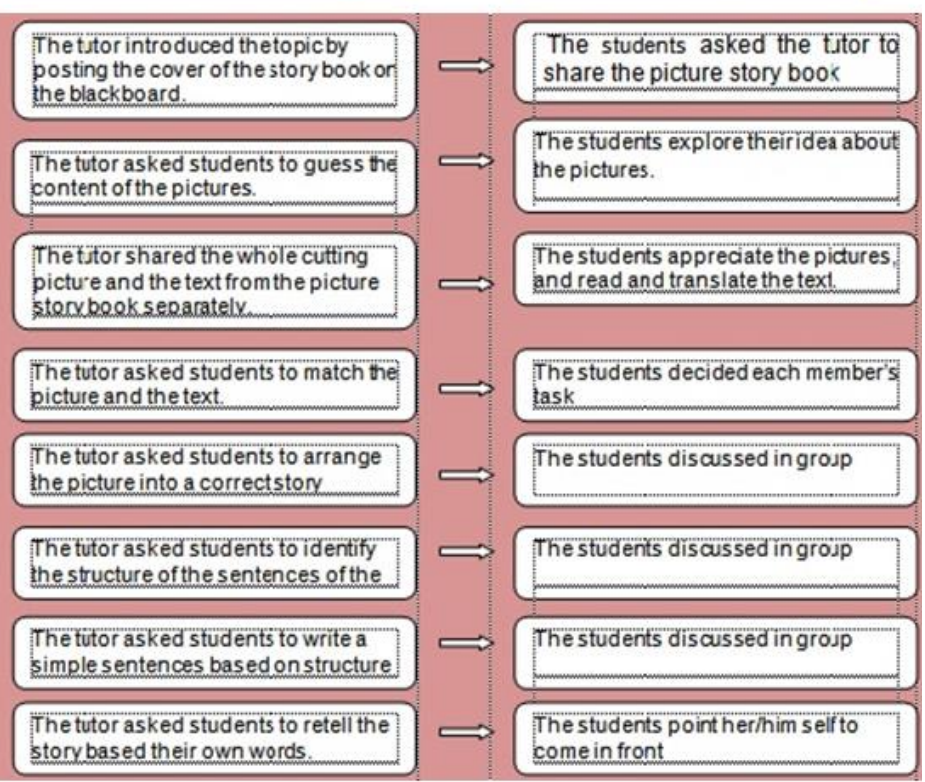

Figure 2. The procedure of the utilization of picture story books 
In short, picture story books can stimulate students' imagination, motivation and creativity. Next, Picture story books develop students' capacity for self-assessment and critical thinking skills. Then, Picture story books can create a learning community in the classroom. In addition, picture story books growth students' confidence and develop students' autonomy to learn.

Mayer (1993 as cited from Rusbulth, 1995: 1) outlines a framework, derived from Paivio's dual coding theory as figure 3 below.

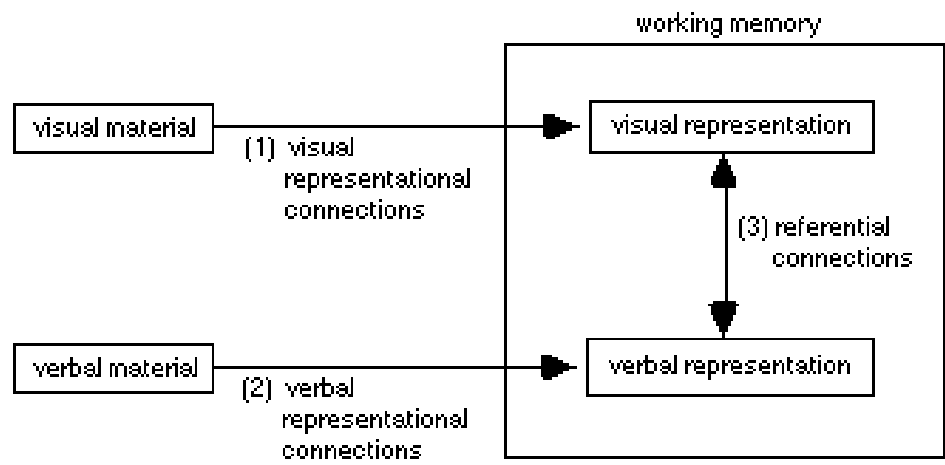

Figure 3. Mayer's dual coding framework

After reading the theory and the previous research, the researcher outline the utilization of picture story books under dual coding framework as figure 4 below.

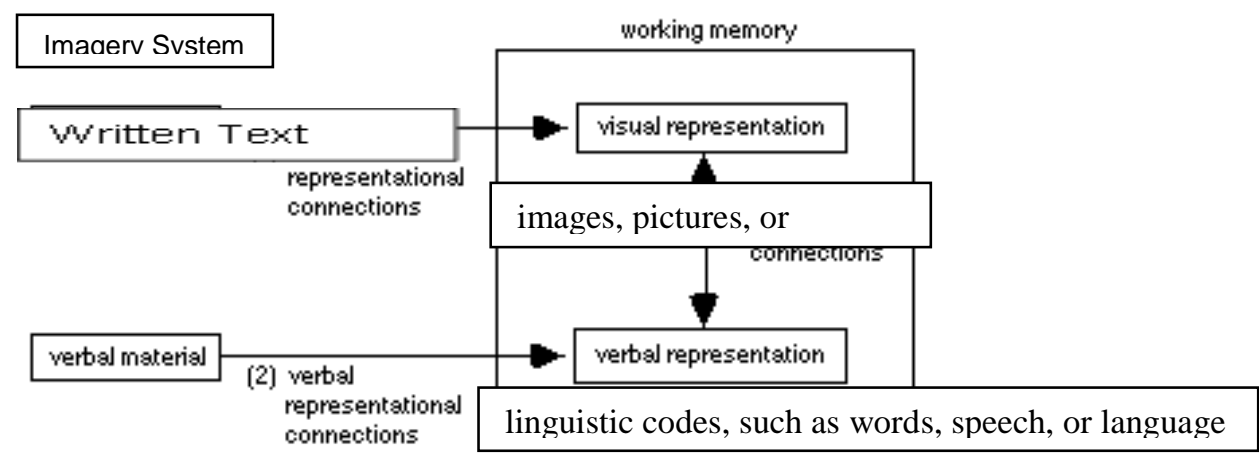

Figure 4. Reading's dual coding framework

This framework shows that images or picture in picture story books and the words or sentences in that books present referential connection in the students' mind. As a result, the students are easy to comprehend the text or the story on the picture story books given.

After doing research, theresearcher drawnn a framework as figure 5 belows.

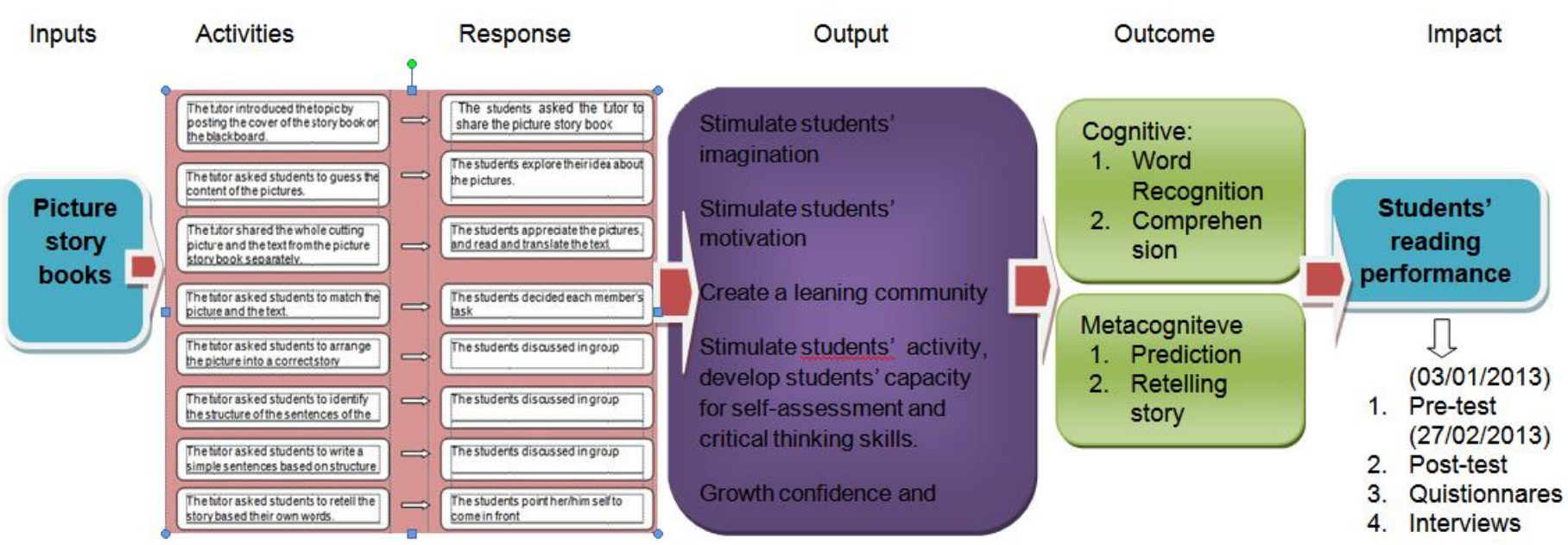

Figure 5. Logical frameworks of utilization picture story books in reading class

When students read a picture story book, students look at the pictures and students read the words and their eyes move back and forth between the pictures and the text then students form a comprehension. This statement is proven by the students' response to the second question of interviews. For example, there was NS who said "In my opinion, the picture lead me to predict the content of the text". At that place was also WB stated " "Yaa, the movie...? It is colorful, menarik hati untuk read dan terus read, and of course memancing kita untuk tahu seluruh isinya". 
Later on, pictures in the picture story book contribute into two aspects of reading; they are word recognition and comprehension. Pictures can aid readers in making inferences and organizing information. Picture help students to easy recognize the word in the text. When students looked the picture, students tried to guess the name of the picture from the text. And when students found unfamiliar word, they tried matching the word with the picture. While, recognizing the words in the text is vital to reading comprehension; if a student cannot understand the language, then they will quite obviously be unable to draw out significance from the composed word. Then, comprehension cannot be successful without the identification of words and retrieval of the word substance, as the understanding of sentences, paragraphs, and passages is increased when mental images are made.

Actually, reflected in the fifth meeting students' response, where the frequency of procedure of utilization picture's story books is boring the students. It means that visual and verbal representation are not the only one which influence the students' reading comprehension in the utilization of picture story books in reading class. We also need to pay attention to the timer frequency.

In other hand, the PKBM Medaso English tutor who also came during the utilization of pictures story books, believe that picture story books is not only budget teaching material but also a such meaningful teaching material. The tutor said that it was her first time to see their students being active in an English class. She also said that picture story books enrich her students' vocabulary. For that reason, she would try to apply picture story books not only in reading class, but also in writing, and speaking class. She also asked the researcher to formulate an approach of using picture story books on listening class.

Here, the researcher provided one sample of students' reading test and its scoring analysis.

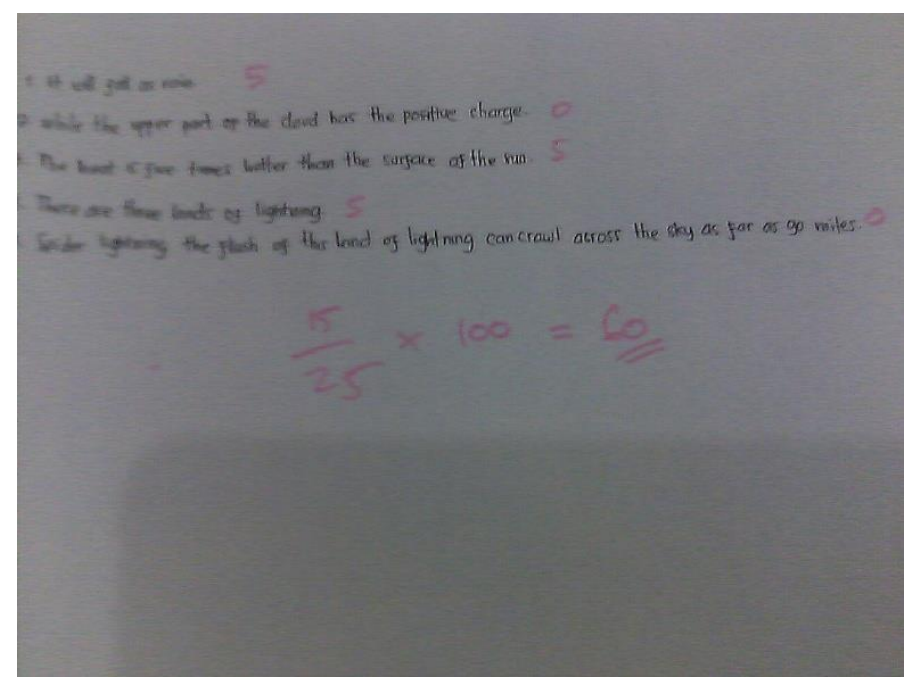

Figure 6. Students Reading Test Score

One important thing to be noted that the utilization of picture story books had changed the researcher teaching perspective. Firstly, before she used picture story books, she only believes that picture story books could stimulate students' prior knowledge. In other hand, the researcher is being hold that that picture story books not only stimulate students' prior knowledge but also encourage students' attitudes as well as students' morality.

\section{Conclusion}

Regarding to the comparison of the mean score and the progression toward the pre-test and the post-test both of the experimental group and the control class, the researcher noted that picture story books affect the students' reading comprehension. In addition, the researcher also noted that the students' perceptions toward the utilization of picture story books are positive. Then, the researcher became suggest the English tutor of Paket B PKBM Medaso to think about the picture story books in teaching the reading. It is also suggested for other researchers to compare picture story books to other teaching materials in order to consider which one provides more gains for the improvement of the English reading comprehension of students. This researcher was only focusing the application of picture story books in reading. It would be valuable if picture story books being applied into other language skills as well as listening, writing, and speaking.

\section{References}

Butcher, K. and Vincent, A. (2000). Integrating Visual and Verbal Knowledge During Classroom Learning with Computer Tutors. [Online] Available: http://act-r.psy.cmu.edu/wordpress/wp-content/uploads/2012/12/757p137.pdf. (September 29, 2012).

Depdiknas. (2006). Kurikulum 2006 : Standar Kompetensi SMA/MA, Jakarta: Dharma Bakti

Jalilehvand, Maryam. (2012). The Effects of Text Length and Pictures on Reading Comprehension of Iranian EFL Students. Faculty of Education University of Malaya. [Online] Available: www.ccsenet.org/journal/index.php/ass/article/view/15408/10903 (September 06, 2012). 


Paivo, A. (2006). Dual Coding Theory and Education. [Online] Available:
http://coral.ufsm.br/tielletcab/Apostilas/DCT_Paivio.pdf (November 05, 2012).

Pan, Y., and Yi-Ching, P. (2009). The Effects of Pictures on the Reading Comprehension of Low-Proficiency Taiwanese English Foreign Language College Students: An Action Research Study. [Online] Available: http://tapchi.vnu.edu.vn/nn_3_09/b.8.pdf (September 06, 2012).

Riyadi, W. (2010). Teaching English Using Story Book to Improve Reading Skill. University of IBN Khaldun BogorIndonesia. [Online] Available: http://universityofibnkhaldunbogor-indonesia.blogspot.co.id/2011/02/teaching-englishusing-story-book-to.html (October 13, 2012).

Rusbult, C. (1995). Visual Thinking in Education( Visual-Verbal Language in Learning \& Teaching ). [Online] Available: http://www.asa3.org/ASA/education/teach/visual.htm (July 15, 2012).

Ryu, Jiyeon, Tingling Lai, Susan Colaric

Clark, J. M., \& Paivio, A. (1991). Dual coding theory and education. Educational psychology review, 3(3), $149-210$.

Sadoski, M., Ernest T., Maximo, R. (2000). Engaging Texts: Effects of Concreteness on Comprehensibility, Interest, and Recall in Four Text Types. Journal of Educational Psychology 92(1),85-95

Teddlie, Ch. and Fen, Y. (2007). Mixed Methods Sampling: A Typology With Examples. Journal of Mixed Methods Research. 